\title{
DIABETIC ALTERATIONS OF INTERSTITIAL CELLS OF CAJAL
}

\author{
Aleksandra Veličkov ${ }^{1}$, Goran Radenković ${ }^{1}$, Vladimir Petrović ${ }^{1}$, \\ Asen Veličkov ${ }^{2}$
}

\begin{abstract}
Interstitial cells of Cajal (ICC) are the cells originating from mesenchyma that represent only $5 \%$ of the cells in the musculature of the gastrointestinal tract (GIT), but they play an important and critical role in smooth muscle function and GIT motility regulation. Absence, reduction or structural alteration of ICC subpopulations are observed in several human gut disorders. This review aims to briefly summarize the current data on morphological and pathophysiological features of ICC subpopulations in the diabetic animal models and in patients. Diabetes mellitus (DM) is a well-known cause of gastroenteropathy and gastrointestinal dysmotilities which occur in up to $30-50 \%$ of patients after 10 years of type I or II diabetes. A loss or dysfunction of ICC has been shown to lead to higher basal tone of the lower esophageal sphincter with spontaneous contractile activity and impaired relaxation, gastric dysrhythmias, gastroparesis, slow intestinal transit, impaired neuroeffector mechanisms with altered visceral afferent signaling in various human dysmotilities and in animal models. The importance of ICC is becoming more evident in diabetic gastrointestinal dysmotility. ICC alterations were associated with gastrointestinal motility disorders in diabetes, such as reduced and arrhythmic slow wave pacing activity and decreased muscle response to the activation of enteric motor neurons. The mechanism of ICC disturbances is multifactorial and the interaction between these factors is a complex one. The pathogenesis of ICC loss includes increased oxidative stress, reduction in growth factors, change in intracellular signaling pathways and regulatory factors. Each of these factors could provide a potential therapy for diabetic gastrointestinal neuropathy.
\end{abstract}

Acta Medica Medianae 2017;56(4):100-107.

Key words: diabetes, Cajal cells, gastroenteropathy

\author{
${ }^{1}$ University of Niš, Faculty of Medicine, Department of Histology \\ and Embryology, Niš, Serbia \\ ${ }^{2}$ Clinic for Orthopedics and Traumasurgery, Second Surgical \\ Clinic, Hospital Coburg, Coburg, Germany \\ Contact: Aleksandra Veličkov \\ 81 Dr Zoran Đinđić Blvd., 18000 Niš, Serbia \\ E-mail: acka13v@gmail.com
}

ders, especially to the ICC changes in diabetic gastroenteropathy. This review aims to briefly summarize the current data on morphological and pathophysiological features of ICC subpopulations in diabetic animal models and in patients. We also review the possible underlying mechanisms of these alterations, with the focus on oxidative stress and growth factors.

\section{Origin of interstitial cells of cajal}

When ICC were first discovered by Cajal, he thought that they were nerve cells (2). However, after the discovery that CD117 (c-kit; a proto-oncogene encoding for the tyrosine kinase receptor) was expressed in ICC $(3,4)$, and that they depended on signaling via Kit receptors for the development and phenotype maintenance (5-7), these cells could be identified at the light microscope level as the cells of mesenchymal origin. The appearance of ICC in the gastrointestinal tract (GIT) occurs about 3 weeks after the appearance of the enteric nervous system, immediately following circular muscle layer differentiation (7-12).

ICC develop independently of the neural 
crest-derived enteric neurons or glia and originate mainly from the Kit-positive mesenchymal mesodermal precursors $(2,13,14)$. As suggested by developmental studies, smooth muscle cells and ICC have a common precursor which expresses ckit $(15,16)$. Afterwards, Kit is indispensable in mesenchymal precursor division during the differentiation towards ICC, and for normal postnatal development, maturation, networking, function, and maintenance of the ICC phenotype in the GIT $(6,13)$.

\section{Classification of interstitial cells of cajal}

ICC are classified into several subtypes based on different distribution patterns, anatomical locations, morphological and functional features. Functional ICC subtypes that exist within the tunica muscularis of the GIT are ICC of the myenteric plexus (ICC-MP) that form a cellular network around the myenteric plexus in the space between the circular and longitudinal muscle layers; intramuscular ICC (ICC-IM), including ICC of the circular (ICC-CM) and longitudinal muscle (ICC-LM); ICC of the submucosa (ICC-SM), at the interface between submucosal connective tissue and the inner muscle layer; ICC of the submucosal plexus (ICC-SMP); ICC of the septa (ICC-SEP), in the connective tissue septa that separate lamellae of the muscle; and ICC of the deep muscular plexus (ICC-DMP), located within the deep muscular plexus region of the small intestine (17-19). The cellular network of ICC-MP is relatively looser in the colon and gastric corpus than in the small intestine, ICC-DMP are present exclusively in the small intestine, and ICC-SM are present only in the coIon and pyloric region of the stomach $(18,20,21)$.

Recent evidence has suggested that ICC subtypes are different in ultra-structural morphology and function, in addition to their different locations $(17,18,22)$.

\section{Morphology and ultrastructure of inter- stitial cells of cajal}

ICC-IM and ICC-SM are similar to the smooth muscle cells, having a spindle-shaped form with bipolar processes that run parallel to the longitudinal axis of cells, while ICC-MP are stellate cells, more multipolar, and with more cytoplasmic processes $(18,23)$. The variations in shape between ICC subtypes are considered to be the effect of the surrounding microenvironment, type of nerve supply, contacts with the smooth muscle cells, and also the type of food passing through that part of the GIT (22).

According to electron microscopy observations, all ICC subtypes share these characteristics: numerous mitochondria, profuse intermediate filaments, presence of surface caveolae, and partially discontinuous basal lamina. ICC also have a welldeveloped smooth and rough endoplasmic reticulum, and gap junctions connecting them both with each other, forming a network throughout the GIT wall, and with smooth muscle cells and nerve varicosities (24). ICC share similar electron microscopy features with smooth muscle cells and fibroblasts, but the lack of thick myofilaments is an important difference from smooth muscle cells; ICC are also thought to be non-contractile cells. On the other hand, fibroblasts do not show caveolaes, rarely have smooth endoplasmic cisternae, intermediate filaments, or a partial basal lamina as ICC do $(18,22,24)$.

\section{Function of icc}

Although ICC represent only $5 \%$ of the cells in the musculature of the GIT, they play an important and critical role in smooth muscle function and GIT motility regulation. The primary evidence for the ICC role in GIT motility control came from knock out animal models with blocked Kit receptors. These animals developed severe gastrointestinal motility dysfunction, with a lack of slow- wave phase peristaltic movements $(25,26)$. ICC-MP subtype regulate slow wave propagation in the stomach and small intestine, and in the colon the source of slow-wave pacemaker activity are ICC-SMP $(18,27,28)$. These ICC subtypes form the networks responsible for gastrointestinal motor control and contractions of the intestinal musculature $(29,30)$, while ICC-IM subtype serves as the mediators of enteric motor neurotransmission (31-34). ICC also play a role in afferent neural signaling and act as mechanoreceptors (35-37).

Absence, reduction or structural alteration of the ICC subpopulations are observed in several human gut disorders, such as achalasia, gastroesophageal reflux disease, gastroparesis, infantile hypertrophic pyloric stenosis, chronic intestinal pseudo-obstruction, Hirschsprung's disease, inflammatory bowel diseases, slow colon transit and severe constipation, and some other GI motility disorders, as well as in gastrointestinal stromal tumors (38-46).

\section{Icc changes in diabetes}

Diabetes mellitus (DM) is a well-known cause of gastroenteropathy and gastrointestinal dysmotilities, which occur in up to $30-50 \%$ of patients after 10 years of type I or II diabetes (47-49). In addition, diabetic gastroenteropathy represents a considerable health care burden and may manifest as dysphagia, heartburn, abdominal pain or discomfort, postprandial fullness, bloating, nausea, vomiting, constipation, diarrhea, and fecal incontinence.

The pathogenesis of diabetic gastroenteropathy is complex and multifactorial. Although it generally has been thought of as a neuropathy, diabetic gastroenteropathy involves not only parasympathetic and sympathetic autonomic nerves, but also enteric glia and neurons, smooth muscle cells, capillary endothelium adjacent to the myenteric ganglia, mucosal endocrine cells and ICC $(50,51)$. Since GIT motility requires an interaction 
between enteric nerves, smooth muscles and ICC, gastrointestinal dysfunction generally involves changes in all of these factors (52). The interaction between these factors is complex, and each of them represents a potential new therapeutic target.

Loss or dysfunction of ICC has been shown to lead to a higher basal tone of the lower esophageal sphincter, with spontaneous contractile activity and impaired relaxation, gastric dysrhythmias, gastroparesis, slow intestinal transit, impaired neuroeffector mechanisms and altered visceral afferent signaling in various human dysmotilities and in animal models (6, 39, 53-57). These gastrointestinal dysmotilities are considered to be the hallmarks of diabetic gastroenteropathy.

ICC of the stomach are shown to be altered in the studies of DM and gastroparesis in animal models. ICC network reduction has been noted in gastric corpus and antrum in the studies with nonobese diabetic (NOD) mice, a model of human type I diabetes $(58,59)$. Ordög (58) demonstrated that ICC density loss started at the corpus region of the gaster and worsened towards the antrum, mainly involving ICC-MP. Although slow waves could still be detected in these areas, they were abnormal in amplitude, as well as in frequency, and these slow waves could not propagate throughout the stomach. In the remaining ICC, ultrastructural changes were observed, such as increased cell processes and loss of contact with adjacent enteric ganglia. In the fundus, there was not any loss of ICC-IM, but there was excess extracellular space between ICC and adjacent enteric nerves. In leptin receptor mutant mice (a type II diabetes mice model), a modest ICC count decline appeared in both ICC-MP and ICC-IM throughout the stomach, small intestine and colon (60).

The loss of ICC was also detected in the gastric fundus and corpus of streptozotocin (STZ)diabetic rats, particularly a depletion of ICC-IM in both circular and longitudinal muscle layers and loss of the ICC-SM (56). Wang also noticed the presence of fibroblast-like cells in the ICC-IM surrounding the enteric ganglia. They were described as immature or recovering ICC which might be involved in tissue healing and repair. Other authors thought these fibroblast-like cells to be a distinct subset of GIT cells that might participate in motility (61).

In a slightly different animal model in which diabetes is induced by the administration of two compounds, STZ and nicotinamide (NA), the resultant diabetes is more similar to human type II diabetes than that in the STZ model; rats manifest moderate hyperglycemia and do not require exogenous insulin to survive (62). Using that model, Velickov demonstrated a decrease of ICC-IM number, discontinuities and breakdown of contacts between them in the lower esophageal sphincter (63) in STZ-NA induced non-insulin-dependent diabetes rats.

ICC-MP reduction is associated with impaired slow wave peristaltic movements and delayed gastric emptying, while ICC-IM reduction or alteration, according to suggestions, is associated with impaired relaxation of the gastric cardia, fundus and antrum (56).

Changes in the enteric nervous system, smooth muscle cells and decreased ICC in humans, similar to animal models, were also demonstrated in diabetic patients mainly with accompanying gastroparesis (64-68). Forster et al. reported the results of gastric biopsy from 14 patients with gastroparesis, including nine patients with DM, and showed a reduction in the number of ICC (65). Similar findings (an ICC loss, with the remaining ICC showing injury) were reported in the Grover's study, where full-thickness gastric biopsy specimens from 40 patients with gastroparesis were examined (including 20 patients with diabetes) (67). In 25 patients with DM and gastric cancer who underwent gastrectomy, the study of the gastric tissue did not show any ICC-MP reduction, but only the reduction of ICC-IM in the inner circular muscle layer (66).

Diminishing ICC populations have been reported in other parts of GIT in diabetes animal model, including the colon and small intestine. In contrast to diabetic gastroparesis, about which several papers have been written $(56,58-60,63)$, there are very few studies evaluating ICC in intestinal dysfunction in diabetes, partly because of the difficulties in investigation and methods available for diagnosis. Furthermore, the results are conflicting $(69,70)$, since a loss or disruption of an ICC network is often followed by structural and functional changes in neuronal and smooth muscle elements. Yamamoto et al., using $a \mathrm{db} / \mathrm{db}$ model of type 2 DM, in addition to stomach, showed a reduced number of ICC in the small intestine and colon (60). Similar ICC losses have been observed in the small intestine and colon of diabetic animals $(71,72)$. In addition, a loss of cKit positive intramuscular ICC has been described in the colon of seven patients suffering both from type 2 diabetes and colon cancer (73). A significant reduction in ICC density in the myenteric region and ICC-IM depletion throughout the entire thickness of the jejunum was shown in the sample obtained from a 38-year-old patient with a 15year history of poorly controlled diabetes and with evidence of diabetic gastroenteropathy (57).

ICC represent an independent source of slow-wave pacemaker movements of GIT, and are also an important factor in neurotransmission between motor neurons, efferent entry from the autonomous nervous system and muscle fibers. It has been proposed that both excitatory and inhibitory neurotransmission between the enteric neurons and smooth muscles are dependent on the presence of ICC-IM. Morphologically, the terminals of enteric motor neurons form tight, synaptic-like contacts with $\operatorname{ICC}(34,74,75)$. It has

been shown that ICC-IM depolarize smooth muscles through gap junctions, when acetylcholine previously released from the enteric motor neurons 
attaches to the Ach receptors of ICC (31). The modulatory role of ICC-IM has also been shown in excitatory neurotransmission, through substance $P$ and neurokinin released from the enteric motor neurons (76). As for inhibitory neurotransmission, IC-IM play an important role in NO-dependent neurotransmission in the lower esophageal sphincter and pyloric sphincters. IC-IM are proposed to be effectors that transduce NO signals into hyperpolarizing responses and in that way modulate and enable sphincters relaxations. A mice model lacking ICC-IM did not show any evidence of nitrergic transmission (77). Wang at al. observed a loss of nerve fibers due to ICC-IM loss and partial depletion of synapse-like connections with ICC-IM (56). A lack of ICC in diabetes affect GIT motility both by reduced ICC-IM that affect neurotransmission, and by impaired pacemaker activity caused by ICC-MP loss. These findings emphasize the importance of ICC and point out how ICC alterations occurring in diabetes are one of the major factors in the development of GIT neuropathy.

\section{in icc}

Mechanism of diabetes-induced changes

DM significantly alters the microenvironment of ICC, leading to decreased survival of these cells. Alterations of ICC in diabetes could have potentially arisen from hyperglycemia and associated oxidative damage, reduction of insulin and growth factor signaling, autoimmune attack, or their combinations, resulting from the imbalance between the factors that damage and factors that regenerate and maintain $\operatorname{ICC}(23,78)$.

Increased oxidative stress, associated with hyperglycemia, was an expected result in the study of diabetic NOD mice with gastroparesis. Along with oxidative stress which accompanies DM, a reduced expression of neuronal NO synthase and stress-induced enzyme heme oxygenase-1(HO-1) is reported, and these agents are potentially cytoprotective and a survival factor for ICC (79). HO-1 is upregulated mainly in macrophages located adjacent to the ICC and enteric nerves. In addition, HO-1 increases the expression of c-kit and neuronal NO synthase and reverses the delay in gastric emptying (80).

Some recent studies investigating ICC loss in NOD mice have shown that hyperglycemia alone is not enough to affect ICC, but reduced insulin-like growth factor-1 (IGF-I) and insulin signaling in diabetes plays the major role in reduced survival of ICC (81). In a recent study, ICC changes and ICC loss have been shown in animal diabetic model with moderate hyperglycemia, and as well in diabetic rats treated with antioxidants where glycaemia was even lower or normal (63), demonstrating that hyperglycemia is not the main cause of ICC alterations. Loss of ICC and nerve structures due to absence of growth factors was consistent with metabolic injury in diabetes, and in addition insulin and IGF-I completely prevented the loss of ICC in murine gastric muscle cell cultures (81). ICC showed better tolerance in terms of maintaining their densities against hyperglycemia than normoglycemia in an absence of insulin or IGF-1 supplements (81). However, ICC do not have insulin receptors; instead, they have receptors for stem cell factor (SCF). SCF is produced by smooth muscle cells and enteric neurons which have the receptors for insulin and IGF-1 and indirectly mediate the effect of insulin and IGF-1 on ICC $(58,81)$. Therefore an interdependence between ICC associated nerve fibers and smooth muscle cells is proposed, as suggested in the studies of ICC-IM and vagal afferent nerves in animal models $(82,83)$ and in patients $(66)$.

Another mechanism of ICC alteration could be autoimmunity. The cause of type 1 diabetes is autoimmune destruction of insulocytes and the same autoimmune process may also interfere with gastrointestinal neuromuscular cells, and the development of autonomic neuropathy (84). Anti-Kit autoantibodies and consequently an ICC loss have been found in a patient with intestinal pseudo-obstruction and paraneoplastic gastroparesis (85), but a similar autoantibody has not been reported in diabetes (78). Furthermore, no signs of apoptosis or lymphocyte infiltration have been found in STZ-NA and STZ diabetic rats $(56,63)$.

\section{Conclusion}

The importance of ICC is becoming more evident in diabetic gastrointestinal dysmotility, and autonomic neuropathy is no longer considered a sole cause of diabetic gastroenteropathy in DM. ICC alterations were associated with gastrointestinal motility disorders in diabetes, such as reduced and arrhythmic slow wave pacing activity, decreased muscle response to the activation of enteric motor neurons, delayed gastric emptying, gastroparesis, slow colon transit $(58,80)$. The mechanism of ICC disturbance is multifactorial and interactions between these factors are complex. The pathogenesis of ICC loss includes increased oxidative stress, reduction in growth factors, change in intracellular signaling pathways and regulatory factors. Each of these factors could provide a potential therapeutic target in diabetic gastrointestinal neuropathy.

However, the questions remain whether neurotransmission can rely solely on ICC and to what degree ICC are involved in neurotransmission, since the number of ICC is considerably lower compared to smooth muscle cells (only $5 \%$ of the muscle layer). In contrast to animal models, there are difficulties in investigating the distribution, function, and alterations of ICC networks in human tissue. ICC cannot be assessed after routine sampling, since GIT biopsies are usually restricted to the mucosal and submucosal layer and obtaining control samples from anatomically identical regions is almost impossible.

Moreover, any translation of these findings into clinical treatments has been a challenge. For instance, oxidative stress has been shown to play an important role in DM enteropathy (86), but the 
use of antioxidant treatments has not been proven to afford an effective protection of $\operatorname{ICC}(63,87)$.

In conclusion, ICC alterations in diabetes certainly contribute to the gastrointestinal symptoms of neuropathic enteropathy, but their exact contribution to this mechanism is still unclear.

\section{Acknowledgments}

This study was supported by the Medical faculty of Niš internal research project number 22.

\section{References}

1. Cajal SR. Histologie du système nerveux de I'homme et des vertébrés. Paris: Maloine 1911; 2:891-942.

2. Wu JJ, Rothman TP, Gershon MD. Development of the interstitial cell of Cajal: origin, kit dependence and neuronal and nonneuronal sources of kit ligand. Journal of neuroscience research 2000; 59: 384401.[CrossRef][PubMed]

3. Ward SM. Interstitial cells of Cajal in enteric neurotransmission. Gut 2000; 47: iv40-43; discussion iv52.[PubMed]

4. Takaki M. Gut pacemaker cells: the interstitial cells of Cajal (ICC). J Smooth Muscle Res 2003;39(5): 137-61 [CrossRef][PubMed]

5. Torihashi S, Ward SM, Nishikawa S, Nishi K, Kobayashi S, Sanders KM. c-kit-dependent development of interstitial cells and electrical activity in the murine gastrointestinal tract. Cell and tissue research 1995; 280: 97-111. [PubMed]

6. Beckett AH, Ro S, Bayguinov Y, Sanders KM, Ward SM. Kit signaling is essential for development and maintenance of interstitial cells of Cajal and electrical rhythmicity in the embryonic gastrointestinal tract. Developmental dynamics : an official publication of the American Association of Anatomists 2007; 236: 60-72. [CrossRef]

7. Radenkovic G, Savic V, Mitic D, Grahovac S, Bjelakovic $M$, Krstic $M$. Development of c-kit immunopositive interstitial cells of Cajal in the human stomach. Journal of cellular and molecular medicine 2010; 14: 1125-34. [PubMed]

8. Wallace AS, Burns AJ. Development of the enteric nervous system, smooth muscle and interstitial cells of Cajal in the human gastrointestinal tract. Cell and tissue research 2005; 319: 367-82. [CrossRef]

9. Radenkovic G. Two patterns of development of interstitial cells of Cajal in the human duodenum. Journal of cellular and molecular medicine 2012; 16: 185-192.[CrossRef][PubMed]

10. Radenkovic G, Ilic I, Zivanovic D, Vlajkovic S, Petrovic V, Mitrovic O. C-kit-immunopositive interstitial cells of Cajal in human embryonal and fetal oesophagus. Cell and tissue research 2010; 340: 427-36. [CrossRef][PubMed]

11. Radenkovic G, Abramovic M. Differentiation of interstitial cells of Cajal in the human distal colon. Cells Tissues Organs 2012; 196: 463-9. [CrossRef] [PubMed]

12. Abramovic M, Radenkovic G, Velickov A. Appearance of interstitial cells of Cajal in the human midgut. Cell Tissue Res 2014; 356: 9-14. [CrossRef][PubMed]

13. Sanders KM, Ordog T, Koh SD, Torihashi S, Ward SM. Development and plasticity of interstitial cells of Cajal. Neurogastroenterology and motility 1999; 11: 311-38. [CrossRef][PubMed]
14. Young HM. Embryological origin of interstitial cells of Cajal. Microscopy research and technique 1999; 47: 303-8. [CrossRef][PubMed]

15. Torihashi S, Ward SM, Sanders KM. Development of c-Kit-positive cells and the onset of electrical rhythmicity in murine small intestine. Gastroenterology 1997; 112: 144-55. [CrossRef]

16. Kluppel M, Huizinga JD, Malysz J, Bernstein A. Developmental origin and Kit-dependent development of the interstitial cells of cajal in the mammalian small intestine. Developmental dynamics 1998; 211: 60-71. [CrossRef]

17. Hanani M, Farrugia G, Komuro T. Intercellular coupling of interstitial cells of cajal in the digestive tract. International review of cytology 2005; 242: 249-82. [CrossRef][PubMed]

18. Komuro T. Structure and organization of interstitial cells of Cajal in the gastrointestinal tract. The Journal of physiology 2006; 576: 653-8. [CrossRef] [PubMed]

19. Streutker CJ, Huizinga JD, Driman DK, Riddell RH. Interstitial cells of Cajal in health and disease. Part I: normal ICC structure and function with associated motility disorders. Histopathology 2007; 50: 176-89. [CrossRef] [PubMed]

20. Rumessen JJ, Peters S, Thuneberg L. Light- and electron microscopical studies of interstitial cells of Cajal and muscle cells at the submucosal border of human colon. Laboratory investigation 1993; 68: 481-95.

21. Nakamura K, Shibata Y. Connexin43 expression in network-forming cells at the submucosal-muscular border of guinea pig and dog colon. Cells Tissues Organs 1999; 165: 16-21. [PubMed]

22. Komuro T. Comparative morphology of interstitial cells of Cajal: ultrastructural characterization. Microscopy research and technique 1999; 47: 26785. [CrossRef]

23. Huizinga JD, Zarate N, Farrugia G. Physiology, injury, and recovery of interstitial cells of Cajal: basic and clinical science. Gastroenterology 2009; 137: 1548-56.[CrossRef][PubMed]

24. Komuro T, Seki K, Horiguchi K. Ultrastructural characterization of the interstitial cells of Cajal. Archives of histology and cytology 1999; 62: 295316.[CrossRef][PubMed]

25. Huizinga JD, Thuneberg L, Kluppel M Malysz J, Mikkelsen HB, Bernstein A. W/kit gene required for interstitial cells of Cajal and for intestinal pacemaker activity. Nature 1995; 373: 347-9. [CrossRef] [PubMed]

26. Ward SM, Burns AJ, Torihashi S, Sanders KM. Mutation of the proto-oncogene c-kit blocks development of interstitial cells and electrical rhythmicity in murine intestine. The Journal of physiology 1994; 480: 91-7. [CrossRef][PubMed] 
27. Lee JC, Thuneberg L, Berezin I, Huizinga JD. Generation of slow waves in membrane potential is an intrinsic property of interstitial cells of Cajal. The American journal of physiology 1999; 277: G40923. [PubMed]

28. Hirst GD, Edwards FR. Role of interstitial cells of Cajal in the control of gastric motility. Journal of pharmacological sciences 2004; 96: 1-10. [CrossRef] [PubMed]

29. Huizinga JD, Lammers WJ. Gut peristalsis is governed by a multitude of cooperating mechanisms. American journal of physiology Gastrointestinal and liver physiology 2009; 296: G1-8. [CrossRef] [PubMed]

30. Hwang SJ, Blair PJ, Britton FC, O'Driscoll KE, Hennig G, Bayguinov YR, et al. Expression of anoctamin 1/TMEM16A by interstitial cells of Cajal is fundamental for slow wave activity in gastrointestinal muscles. The Journal of physiology 2009; 587: 4887-04. [CrossRef][PubMed]

31. Ward SM, Beckett EA, Wang X, Baker F, Khoyi M, Sanders KM. Interstitial cells of Cajal mediate cholinergic neurotransmission from enteric motor neurons. The Journal of neuroscience 2000; 20: 1393-403. [PubMed]

32. Suzuki H, Ward SM, Bayguinov YR, Edwards FR, Hirst GDS. Involvement of intramuscular interstitial cells in nitrergic inhibition in the mouse gastric antrum. The Journal of physiology 2003; 546: 75163. [CrossRef][PubMed]

33. Sanders KM, Salter AK, Hennig GW, Koh SD, Perrino BA, Ward SM, et al. Responses to enteric motor neurons in the gastric fundus of mice with reduced intramuscular interstitial cells of cajal. Journal of neurogastroenterology and motility 2014; 20: 171-84. [CrossRef]

34. Ward SM, Sanders KM. Involvement of intramuscular interstitial cells of Cajal in neuroeffector transmission in the gastrointestinal tract. The Journal of physiology 2006; 576: 675-82. [CrossRef][PubMed]

35. Thuneberg L, Peters S. Toward a concept of stretch-coupling in smooth muscle. I. Anatomy of intestinal segmentation and sleeve contractions. The Anatomical record 2001; 262: 110-124. [CrossRef][PubMed]

36. Won KJ, Sanders KM, Ward SM. Interstitial cells of Cajal mediate mechanosensitive responses in the stomach. Proceedings of the National Academy of Sciences of the United States of America 2005; 102: 14913-18. [CrossRef]

37. Garcia-Lopez P, Garcia-Marin V, Martinez-Murillo R, Freire M. Updating old ideas and recent advances regarding the Interstitial Cells of Cajal. Brain research reviews 2009; 61: 154-69. [CrossRef] [PubMed]

38. Faussone-Pellegrini MS, Cortesini C. The muscle coat of the lower esophageal sphincter in patients with achalasia and hypertensive sphincter. An electron microscopic study. Journal of submicroscopic cytology 1985; 17: 673-85.

39. Vanderwinden JM, Rumessen JJ. Interstitial cells of Cajal in human gut and gastrointestinal disease. Microscopy research and technique 1999; 47: 34460. [CrossRef][PubMed]

40. Zarate N, Mearin F, Wang XY, Hewlett B, Huizinga JD, Malagelada J-R. Severe idiopathic gastroparesis due to neuronal and interstitial cells of Cajal degeneration: pathological findings and management. Gut 2003; 52: 966-970. [CrossRef] [PubMed]
41. Gockel I, Bohl JR, Eckardt VF, Junginger T. Reduction of interstitial cells of Cajal (ICC) associated with neuronal nitric oxide synthase (nNOS) in patients with achalasia. The American journal of gastroenterology 2008; 103: 856-64. [CrossRef][PubMed]

42. Jain D, Moussa K, Tandon M, Culpepper-Morgan J, Proctor DD. Role of interstitial cells of Cajal in motility disorders of the bowel. The American journal of gastroenterology 2003; 98: 618-24. [CrossRef][PubMed]

43. Streutker CJ, Huizinga JD, Campbell F, Ho J, Riddell $\mathrm{RH}$. Loss of CD117 (c-kit)- and CD34-positive ICC and associated CD34-positive fibroblasts defines a subpopulation of chronic intestinal pseudoobstruction. The American journal of surgical pathology 2003; 27: 228-35. [CrossRef][PubMed]

44. Rolle U, Piotrowska AP, Nemeth L, Puri P. Altered distribution of interstitial cells of Cajal in Hirschsprung disease. Archives of pathology \& laboratory medicine 2002; 126: 928-33. [PubMed]

45. Yamataka A, Kato $Y$, Tibboel D, Murata Y, Sueyoshi N, Fujimoto T. A lack of intestinal pacemaker (c-kit) in aganglionic bowel of patients with Hirschsprung's disease. Journal of pediatric surgery 1995; 30: 441-4. [CrossRef][PubMed]

46. Kindblom LG, Remotti HE, Aldenborg F, MeisKindblom JM. Gastrointestinal pacemaker cell tumor (GIPACT): gastrointestinal stromal tumors show phenotypic characteristics of the interstitial cells of Cajal. The American journal of pathology 1998; 152: 1259-69.[PubMed]

47. Vinik AI, Maser RE, Mitchell BD, Freeman R. Diabetic autonomic neuropathy. Diabetes care 2003; 26: 1553-79. [CrossRef][PubMed]

48. Boulton AJ, Vinik AI, Arezzo JC, Bril V, Feldman EL, Freeman R. Diabetic neuropathies: a statement by the American Diabetes Association. Diabetes care 2005; 28: 956-62. [CrossRef][PubMed]

49. Sfarti C, Trifan A, Hutanasu C, Cojocariu C, Singeap AM, Stanciu C. Prevalence of gastroparesis in type 1 diabetes mellitus and its relationship to dyspeptic symptoms. Journal of gastrointestinal and liver diseases 2010; 19: 279-84. [PubMed]

50. Ordog T, Hayashi Y, Gibbons SJ. Cellular pathogenesis of diabetic gastroenteropathy. Minerva gastroenterologica e dietologica 2009; 55: 315-43.

51. Bagyanszki M, Bodi N. Diabetes-related alterations in the enteric nervous system and its microenvironment. World journal of diabetes 2012; 3: 80-93. [CrossRef][PubMed]

52. Kashyap P, Farrugia G. Diabetic gastroparesis: what we have learned and had to unlearn in the past 5 years. Gut 2010; 59: 1716-26. [CrossRef] [PubMed]

53. Sivarao DV, Mashimo HL, Thatte HS, Goyal RK. Lower esophageal sphincter is achalasic in nNOS(/-) and hypotensive in $\mathrm{W} / \mathrm{W}(\mathrm{v})$ mutant mice. Gastroenterology 2001; 121: 34-42. [CrossRef] [PubMed]

54. Dixit D, Zarate N, Liu LW, Boreham DR, Huizinga JD. Interstitial cells of Cajal and adaptive relaxation in the mouse stomach. American journal of physiology Gastrointestinal and liver physiology 2006; 291: G1129-36. [CrossRef]

55. Farre $R$, Wang $X Y$, Vidal $E$. Interstitial cells of Cajal and neuromuscular transmission in the rat lower oesophageal sphincter. Neurogastroenterology and motility 2007; 19: 484-96. [CrossRef]

56. Wang XY, Huizinga JD, Diamond J, Liu LWC. Loss of intramuscular and submuscular interstitial cells of 
Cajal and associated enteric nerves is related to decreased gastric emptying in streptozotocininduced diabetes. Neurogastroenterology and motility 2009; 21: 1095-e92. [CrossRef]

57. He CL, Soffer EE, Ferris CD, Walsh RM, Szurszewski $\mathrm{JH}$, Farrugia G. Loss of interstitial cells of cajal and inhibitory innervation in insulin-dependent diabetes. Gastroenterology 2001; 121: 427-34. [CrossRef] [PubMed]

58. Ordog T, Takayama I, Cheung WK, Ward SM, Sanders KM. Remodeling of networks of interstitial cells of Cajal in a murine model of diabetic gastroparesis. Diabetes 2000; 49: 1731-9. [CrossRef][PubMed]

59. Horvath VJ, Vittal $H$, Lorincz A, Chen $H$, AlmeidaPorada G, Redelman D. Reduced stem cell factor links smooth myopathy and loss of interstitial cells of cajal in murine diabetic gastroparesis. Gastroenterology 2006; 130: 759-70. [CrossRef]

60. Yamamoto T, Watabe K, Nakahara M, Ogiyama H, Kiyohara T, Tsutsui $\mathrm{S}$, et al. Disturbed gastrointestinal motility and decreased interstitial cells of Cajal in diabetic $\mathrm{db} / \mathrm{db}$ mice. Journal of gastroenterology and hepatology 2008; 23: 660-7. [CrossRef]

61. Horiguchi K, Komuro T. Ultrastructural observations of fibroblast-like cells forming gap junctions in the $\mathrm{W} / \mathrm{W}(\mathrm{nu})$ mouse small intestine. Journal of the autonomic nervous system 2000; 80: 142-7. [CrossRef]

62. Masiello P, Broca C, Gross R, Roye M, Manteghetti $M$, Hillaire-Buys $D$, et al. Experimental NIDDM: development of a new model in adult rats administered streptozotocin and nicotinamide. Diabetes 1998; 47: 224-229. [CrossRef][PubMed]

63. Velickov A, Mitrovic O, Djordjevic B, Sokolovic D, Zivkovic V, Velickov A, et al. The effect of bilberries on diabetes-related alterations of interstitial cells of Cajal in the lower oesophageal sphincter in rats. Histology and histopathology 2017, 32: 639-47. [PubMed]

64. Pasricha PJ, Pehlivanov ND, Gomez G, Vittal H, Lurken MS, Farrugia G. Changes in the gastric enteric nervous system and muscle: a case report on two patients with diabetic gastroparesis. BMC gastroenterology 2008; 8: 21. [CrossRef][PubMed]

65. Forster J, Damjanov I, Lin Z, Sarosiek I, Wetzel P, McCalluml RW. Absence of the interstitial cells of Cajal in patients with gastroparesis and correlation with clinical findings. Journal of gastrointestinal surgery 2005; 9: 102-8. [CrossRef]

66. Iwasaki H, Kajimura M, Osawa S, Osawa S, Kanaoka S, Furuta $T$, et al. A deficiency of gastric interstitial cells of Cajal accompanied by decreased expression of neuronal nitric oxide synthase and substance $P$ in patients with type 2 diabetes mellitus. Journal of gastroenterology 2006; 41: 1076-87. [CrossRef][PubMed]

67. Grover M, Farrugia G, Lurken MS, Bernard CE, Faussone-Pellegrini MS, Smyrk TC, et al. Cellular changes in diabetic and idiopathic gastroparesis. Gastroenterology 2011; 140: 1575-85. [CrossRef] [PubMed]

68. Kim ER, Kim KM, Lee JY, Jood M, Kim S, Noh JH, et al. The clue of Interstitial Cell of Cajalopathy (ICCpathy) in human diabetic gastropathy: the ultrastructural and electrical clues of ICCpathy in human diabetic gastropathy. Experimental and toxicologic pathology 2012; 64: 521-6. [CrossRef]

69. Forrest A, Huizinga JD, Wang XY, Liu L, Parsons M. Increase in stretch-induced rhythmic motor activity in the diabetic rat colon is associated with loss of
ICC of the submuscular plexus. American journal of physiology Gastrointestinal and liver physiology 2008; 294: G315-26. [CrossRef] [PubMed]

70. Imaeda K, Takano H, Koshita M, Yamamoto $Y$, Joh $T$, Suzuki $H$. Electrical properties of colonic smooth muscle in spontaneously non-insulin-dependent diabetic rats. Journal of smooth muscle research 1998; 34: 1-11. [CrossRef][PubMed]

71. Lammers WJ, Al-Bloushi HM, Al-Eisaei SA, Al-Dhaheri FA, Stephen B, John $R$, et al. Slow wave propagation and plasticity of interstitial cells of Cajal in the small intestine of diabetic rats. Experimental physiology 2011; 96: 1039-1048. [CrossRef][PubMed]

72. Lin L, Xu LM, Zhang W, Ge Y, Tang Y, Zhang H, et al. Roles of stem cell factor on the depletion of interstitial cells of Cajal in the colon of diabetic mice. American journal of physiology Gastrointestinal and liver physiology 2010; 298: G241-7. [CrossRef] [PubMed]

73. Nakahara M, Isozaki K, Hirota S, Vanderwinden JM, Takakura R, Kinoshita K, et al. Deficiency of KITpositive cells in the colon of patients with diabetes mellitus. Journal of gastroenterology and hepatology 2002; 17: 666-70. [CrossRef] [PubMed]

74. Ward SM, McLaren GJ, Sanders KM. Interstitial cells of Cajal in the deep muscular plexus mediate enteric motor neurotransmission in the mouse small intestine. The Journal of physiology 2006; 573: 147-59. [CrossRef][PubMed]

75. Beckett EA, Takeda Y, Yanase H, Sanders K, Ward SM. Synaptic specializations exist between enteric motor nerves and interstitial cells of Cajal in the murine stomach. The Journal of comparative neurology 2005; 493: 193-206. [CrossRef] [PubMed]

76. Iino S, Ward SM, Sanders KM. Interstitial cells of Cajal are functionally innervated by excitatory motor neurones in the murine intestine. The Journal of physiology 2004; 556: 521-30. [CrossRef][PubMed]

77. Ward SM, Morris G, Reese L, Wang XY, Sanders KM. Interstitial cells of Cajal mediate enteric inhibitory neurotransmission in the lower esophageal and pyloric sphincters. Gastroenterology 1998; 115: 314-29. [CrossRef]

78. Ordog T. Interstitial cells of Cajal in diabetic gastroenteropathy. Neurogastroenterology and motility 2008; 20: 8-18. [CrossRef][PubMed]

79. Choi KM, Gibbons SJ, Roeder JL, Lurken MS, Zhu J, Wouters MM, Miller SM, et al. Regulation of interstitial cells of Cajal in the mouse gastric body by neuronal nitric oxide. Neurogastroenterology and motility 2007; 19: 585-95. [CrossRef] [PubMed]

80. Choi KM, Gibbons S], Nguyen TV, Stoltz G], Lurken MS, Ordog $T$, et al. Heme oxygenase-1 protects interstitial cells of Cajal from oxidative stress and reverses diabetic gastroparesis. Gastroenterology 2008; 135: 2055-64. [CrossRef][PubMed]

81. Horvath VJ, Vittal H, Ordog T. Reduced insulin and IGF-I signaling, not hyperglycemia, underlies the diabetes-associated depletion of interstitial cells of Cajal in the murine stomach. Diabetes 2005; 54: 1528-33. [CrossRef][PubMed]

82. Huizinga JD, Reed DE, Berezin I, Wang XY, Valdez DT, Liu LWC, et al. Survival dependency of intramuscular ICC on vagal afferent nerves in the cat esophagus. American journal of physiology Regulatory, integrative and comparative physiology 2008; 294: R302-10. [CrossRef] [PubMed]

83. Powley TL, Wang XY, Fox EA, Phillips RJ, Liu LWC, Huizinga JD, et al. Ultrastructural evidence for communication between intramuscular vagal mechanoreceptors and interstitial cells of Cajal in 
the rat fundus. Neurogastroenterology and motility 2008; 20: 69-79. [PubMed]

84. Vinik AI, Anandacoomaraswamy D, Ullal J. Antibodies to neuronal structures: innocent bystanders or neurotoxins? Diabetes care 2005; 28: 2067-72. [CrossRef][PubMed]

85. Pardi DS, Miller SM, Miller DL, Burgart ${ }^{\prime}$, Szurszewski JH, Lennon VA, et al. Paraneoplastic dysmotility: loss of interstitial cells of Cajal. The
American journal of gastroenterology 2002; 97: 1828-33. [CrossRef][PubMed]

86. Kashyap P, Farrugia G. Oxidative stress: key player in gastrointestinal complications of diabetes. Neurogastroenterology and motility 2011; 23: 111-4. [CrossRef][PubMed]

87. Golbidi S, Ebadi SA, Laher I. Antioxidants in the treatment of diabetes. Current diabetes reviews 2011; 7: 106-25. [CrossRef][PubMed]

\title{
Revijalni rad
}

UDC: 611.018:616.379-008.64 doi: $10.5633 / \mathrm{amm} .2017 .0416$

\section{PROMENE INTERSTICIJALNIH KAHALOVIH ĆELIJA KOD DIJABETESA}

\author{
Aleksandra Veličkov ${ }^{1}$, Goran Radenković ${ }^{1}$, Vladimir Petrović ${ }^{1}$, \\ Asen Veličkov ${ }^{2}$
}

\author{
${ }^{1}$ Univerzitet u Nišu, Medicinski fakultet, Katedra za histologiju i embriologiju, Niš, Srbija \\ ${ }^{2}$ Klinika za ortopediju i traumahirurgiju, Druga hiruška klinika, Klinika Koburg, Nemačka \\ Kontakt: Aleksandra Veličkov \\ Bul. dr Zorana Đinđića 81, 18000 Niš, Srbija \\ E-mail: acka13v@gmail.com
}

Intersticijalne Kahalove ćelije (IĆK) su mezenhimalne ćelije koje predstavljaju samo $5 \%$ ćelijskih populacija muskularnog sloja gastrointestinalnog trakta (GIT), ali imaju značajnu ulogu u regulaciji GIT motiliteta i funkciji glatko-mišićnih ćelija. Odsustvo, re-dukcija ili strukturalne promene subpopulacija IĆK opisane su kod više poremećaja GIT-a. Cilj ovog preglednog članka bio je da rezimira aktuelne podatke o morfološkim i patohistološkim karakteristikama IĆK subpopulacija kod bolesnika sa dijabetesom i paralelnim životinjskim modelima. Kod bolesnika sa desetogodišnjim dijabetesom (tip I i II), prevalencija gastroenteropatija i poremećaji motiliteta GIT-a je čak 30-50\%. Gubitak ili disfunkcija IĆK dovode do povećanog bazalnog tonusa donjeg ezofagealnog sfinktera sa spontanom kontraktilnom aktivnošću i poremećenom relasacijom, disaritmije želuca, gastropareze, sporog intestinalnog tranzita, izmenjene neuroefektorne mehanizme praćene promenama visceralne aferentne signalizacije i dismotiliteta kod čoveka i životinjskih modela. Značaj IĆK postaje sve više evidentan kod dijabetične gastroenteropatije. Poremećaji GIT motiliteta uzrokovani IĆK promenama povezani su su redukovanim i disaritmičnim sporim ritmičkim talasima i smanjenim odgovorom glatkih mišića na aktivaciju enteričkih motornih neurona. Mehanizam poremećaja IĆK kod dijabetesa je multifaktorijalan, obuhvata povećan oksidativni stres, redukovane faktore rasta, promene intraćelijske signalizacije i regulatornih faktora, a interakcija ovih faktora je kompleksna. Svaki od ovih činilaca može predstavljati potencijalni terapijski pristup kod dijabetične gastroenteropatije.

Acta Medica Medianae 2017;56(4):100-107.

Ključne reči: dijabetes, intersticijalne ćelije Kahala, gastroenteropatija 